\title{
Pathological changes inducing by Brucella mellitensis in mice immunized with Culture Filtrate Brucella mellitensis Antigens (SCFAgs) and chitosan
}

\author{
A. M. M.ALnashy \\ M. j. A.AL- Jubory.
}

Coll.of Vet. Med. /Unive. Baghdad

\begin{abstract}
In order to determine the influence of Culture Filtrate Brucella mellitensis Antigens (CFAgs) on B. mellitensis infection in chatosan immunostimulater mice, sixty for white mice, both sex,78 weeks age were divided randomly into for groups. $1^{\text {st }}$ group $(n=16)$ was immunized with $0.4 \mathrm{ml}$ of CFSAgs B. mellitensis (concentration of protein $(4.2 \mathrm{mg} / \mathrm{ml}$ ) , $\mathrm{i} / \mathrm{p}$ two doses, 2 weeks intervals. $2^{\text {nd }}$ group $(\mathrm{n}=16)$ was feed on diet supplement with chitosan, $(1 \mathrm{mg} / \mathrm{kg} \mathrm{B}$.W 4 weeks. group. $3^{\text {ed }}$ group $(\mathrm{n}=1)$ was inoculated with $(0.4 \mathrm{ml}) \mathrm{I} / \mathrm{P}$ with $1 \times 10^{9} \mathrm{CFU} / \mathrm{ML}$ of viable virulent B. mellitensis and was served as control positive group. $4^{\text {th }}$ group $(n=16)$ was inoculated with $0.5 \mathrm{ml}$ sterile normal saline. Cellular and humoral immune response were recorded at 28-30 day post immunization, skin test and passive heam agglutination test respectively, then all animals of immunized and feed chatosan groups were challenge with $B$. mellitensis as control positive group. The results explained that dead for animals in cotral positive during 15 days post inoculation with virulent viable B. mellitensi with very heavy bacterial isolation, from animal of control positive group post infection The results revealed that immunization with CFSAgs elicited both humoral and cellular immune responses, the level values of both arms of immune response also result reveald that immunization with CFSAgs + chatosan elicited both humoral and cellular immune responses higher than other group , Severe pathological lesions were seen in examined organs of control positive group but these lesions are mild or few in animal immunization with CFSAgs + chatosan. The main lesions in examined organs of these animals are suppurative inflammation ,small grnulomma .. We conclusion that immunization with CFSAgs + chatosan can improve the immune responses in the animals that are suffering from Brucella mellitensis infection

KEYWORDS B. mellitensis.. CFB.MAgs. Chatosan
\end{abstract}

\section{Introduction}

Brucellosis is an important ,highly contagious, economic, widespread zoonotic disease which is caused by the genus of Brucella( 1). Brucella melitensis and Brucella abortus ,a facultative intracellular gram-negative coccobacilli, are the two most common causative agents of Brucellosis in both human ,Ovine and cattle The disease causes by these organisms characterized by undulant fever, chronic fatigue, arthritis, endocarditis, meningitis and orchitis in humans and the infection become chronic if not treated, in addition the symptoms may recur years after the original infection(
2). Chitosan is a modified natural carbohydrate polymer derived from chitin, which occurs principally in Arthropod which produce commercially by deacetcylation of chitin which is the structure element in the exoskeleton of crustaceans ( such as crabs ,pandalus borealis,shrimp) and cell wall of fungi( 3 ) chatosan play role in stimulated immunity both humeral and cellular immunity(4) In the present study, we an attempt to improve the immunogenicity of the culture filtrate B.melitensis antigens in immunized animals fed diet supplement with chitosan( 5) 


\section{Materials and Methods}

Spicies of baccteria take from pathological branch from vetrinarian medicine collage of Baghaded and confirm biochemical examination of bacteria and examination virulence of Brucella meillitensis

\section{Preparation of Brucella meillitensis :}

Culture filtrated Brucella meillitensis antigens (CFSAgs):

Brucella meillitensis was cultured on 15 Tryptic soya agar plates and incubated at $37 \mathrm{c}^{\circ}$ for $24-48 \mathrm{hrs}$ then harvested) by PBS 7.2 , and the bacterial suspension was centrifuged at $3000 \mathrm{rpm} 4{ }^{\circ} \mathrm{C} / 30$ minutes. The supernatant was taken in sterile method and filtrated by Millipore filter. The supernatant fluid was examined by $G$ stain and culturing on blood agar to confirm sterility of these antigen.

- The total protein concentration of this antigen was measured according to Biuret procedure $(4.2 \mathrm{mg} / \mathrm{ml})$ bacteria consider as(CFBAgs).. Than part of this supernatant solution was cold centrifuged at 23000rpm for (30) minutes ,the supernatant was consider as soluble culture filtrate Brucella melitensis antigen (SCFBAgs). The supernatant fluid was examined by gram stain and culturing on blood agar to confirm sterility of these antigen.

\section{- Whole Brucella Sonicated Ag. (WSB} Ag):

It was prepared as follow (Mitove $\boldsymbol{e t}$ al., 1992):

- Brucella mellitensis cultured on Tryptic soya agar, incubated at $37{ }^{\circ} \mathrm{C}$ for $24-48$ hrs. and harvested by PBS 7.2, centrifuged at $3000 \mathrm{rpm} 4{ }^{\circ} \mathrm{C} / 30$ minutes then washed the precipitate three times with $\mathrm{PBS}$, and the precipitate was re-suspended with PBS and put in the universal tube.

- Sonication: the universal tube that contained Brucella mellitensis suspension was placed in the ultrasonicator (type Karl Klob - Germany) at 12 Peak with 2 minutes intervals between them, for 30 minutes in cold environment (ice).

- The sonicated suspension was centrifuged at $23000 \mathrm{rpm}$ for 30 minutes.

- The supernatant fluid was examined by gram stain and culturing on blood agar to confirm sterility of these antigen.

- The total protein concentration of this antigen, which measured according to Biuret procedure $16 \mathrm{mg} / \mathrm{ml}$ and it was diluted to become $0.5 \mathrm{mg} / \mathrm{ml}$ this antigens was considered as soluble sonicated Brucella antigens(SBMAgs)

Determination of the virulent and Challenge Dose S.aureus:

Brucella Mellitensis cultured on a Tryptic soya agar nd incubated at $37^{\circ} \mathrm{C}$ for $24-48 \mathrm{hrs}$. Two mice were inoculated I/P with $0.2 \mathrm{ml}$ of bacterial growth ,the animals were scarified at $72 \mathrm{hrs}$ post inoculated and pieces from internal organs were culture on the blood agar for $24-48 \mathrm{hrs}$ at $37 \mathrm{c}^{\circ}$ and this process was recurrent until the inoculated animals were dead during hrs. 12 mice both sex were divided into three equal group and they were inoculated with $0.2 \mathrm{ml}$ of bacterial suspension containing $1 \times 10^{8}, 1 \times 10^{9}$ and $1 \times 10^{10} \mathrm{CFU}$ of virulent Brucella Mellitensis respectively and we recorded the number of dead animal during 48-72 hrs post inoculation. The dose which killed half number of inoculated

animal was consider as a challenge dose $\left(1 \times 10^{9} \quad\right.$ CFU/ML) (5). The preparation of the bacterial suspension of the counting was made using (7).

\section{Preperation of chatosan Diet}

Commercial assorted pellets were grinded by food grinder and weighed, $1 \mathrm{gm}$ of Chitosan was added to each kilogram of grinded pellets mixed well and converted into paste which passed through meat grinder to mould the paste into the original pellets from, left exposed to dry in room temperature (8).

\section{Experimental Design:}


One seventy four mice, both sex , 7-8 weeks old were divided randomly into (5) groups and treated as the following : $1.1^{\text {st }}$ group $(\mathrm{n}=16)$ was immunized with $0.4 \mathrm{ml}$ of Brucella mellitensis CFSAgs (concentration of $\operatorname{protein}(4.2 \mathrm{mg} / \mathrm{ml}), \mathrm{i} / \mathrm{p}$ two doses, 2 weeks intervals.

$.2-2^{\text {nd }}$ group ( $\left.n=16\right)$ was immunized with CFSAgs as 1st group and feed on diet supplement with chatosan $(1 \mathrm{~g} / \mathrm{kg})$ for week $3-3^{\text {rd }}$ group $(n=16)$ was inoculated with $(0.4 \mathrm{ml}) \mathrm{I} / \mathrm{P}$ with $1 \mathrm{X} 10^{9} \mathrm{CFU} / \mathrm{ML}$ of viable virulent. Brucella mellitensisa and was served as control positive group.

$4-4^{\text {th }}$ group $(n=16)$ was inoculated with $0.5 \mathrm{ml}$ sterile normal saline.

Cellular immune response was detected at 28 days post immunization with skin test and at day 30 post immunization ,6 animals from $1^{\text {st }}, 2^{\text {nd }}, 3^{\text {ed }}, 4^{\text {th }}$ groups were sacrificed for collection of blood and to determine the homural immune response ,then remain animals of $1^{\text {st }}, 2^{\text {nd }}, 3^{\text {rd }}, 4^{\text {th }}$, groups were challenge I/P with1X10 $10^{9} \mathrm{CFU} / \mathrm{ML}$ of viable virulent Brucella mellitensis Five animals from each group were sacrificed at,30 days post challenge and post-mortem examination was done, pieces from internal organs were taken for bacterial isolation and other pieces were fixed in $10 \%$ neutrals buffer formaldehyde (72 hrs) for histopathological examination.

Plan of study:

Delayed Type Hypersensitivity Test (DTH):

The test Was conducted according to (8).

Passive Hem agglutination Test (PHA Test)

The test Was conducted according to(9).

\section{Immunization:}

\section{Results and Discussion}

\begin{tabular}{|c|c|c|c|c|}
\hline \multicolumn{5}{|c|}{ Skin Test: (table:1). } \\
\hline \multirow[t]{2}{*}{ group } & \multicolumn{4}{|c|}{ Mean skin thickness } \\
\hline & \multicolumn{2}{|c|}{ Agaist SCFBMAs } & \multicolumn{2}{|c|}{ Against SSBMAs } \\
\hline \multirow[t]{2}{*}{1} & $24 \mathrm{hr}$ & $48 \mathrm{hr}$ & $24 \mathrm{hr}$ & $48 \mathrm{hr}$ \\
\hline & $\begin{array}{r}0.7 \pm 0.17 \\
\text { a A }\end{array}$ & $\begin{array}{c}0.090 .52 \pm \\
\mathrm{Aa}\end{array}$ & $\begin{array}{c}0.28 \pm 0.64 \\
\mathrm{Ab}\end{array}$ & $\begin{array}{l}0.22 \pm 0.53 \\
\mathrm{Ab}\end{array}$ \\
\hline 2 & $\begin{array}{r}0.571 .9 \pm \\
\mathrm{Ba}\end{array}$ & $\begin{array}{l}1.58 \pm 0.17 \\
\mathrm{Ba}\end{array}$ & $\begin{array}{c}0.25 \pm 1.32 \\
\mathrm{Bb}\end{array}$ & $\begin{array}{l}0.240 .91 \pm \\
\mathrm{Cb}\end{array}$ \\
\hline 4 & 0 & 0 & 0 & 0 \\
\hline
\end{tabular}

At $24 \mathrm{hr}$ post testing, The results showed that the mean values of skin thickness against SCFSAgsand against SSSAgs( $0.7 \pm 0.7,0.28 \pm 0.64)$ were lower in $1^{\text {st }}$ group as compared with 2 group ( 1.9 \pm 0.57 $, 1.32 \pm 0.25)$ respectively. At $48 \mathrm{hr}$ post examination,the mean values of DTH against both SCFSAgs and SSSAgs were decline in $1^{\text {st }}$ group $(0.52 \pm 0.09$, $0.22 \pm 0.53)$ and in 2 group $(1.58 \pm 0.17$ $, 0.91 \pm 0.24)$ respectively in (table: 1 ). The results of passive haemagglutination examination revealed the serum Abs titers in $1^{\text {st }}$ group $(108.8 \pm 19.2)$ lower than in 4 group which consider ( $245.4 \pm 74.63$ ) (table: 2). 
PassiveHeamagglutination test (table: 2).

\begin{tabular}{|l|l|}
\hline $\mathrm{G}$ & $\begin{array}{l}\text { Mean values of antibodies titers at } \\
\text { 30days post-immunization, ( (Mean } \pm \text { S.E) }\end{array}$ \\
\hline 1 & $\begin{array}{l}108.8 \pm 19.2 \\
\mathrm{~A}\end{array}$ \\
\hline 2 & $\begin{array}{l}245.4 \pm 74.63 \\
\mathrm{~B}\end{array}$ \\
\hline 4 & 0 \\
\hline
\end{tabular}

The results of Delayed Type Hypersensitivity (DTH) in the present study may indicated that the CFBAgs elicited cell mediated immune response in immunized animals, since DTH is the essential type of CMT and it is mediated by CD4+Tcells and CD8+Tcell cytokines production, these evidence was supported idea that mentioned by $(8,9)$, who reported that Candida CFAgs and Candida CFAgs were stimulated CMI. The induction DTH reaction in animals immunized with CFBAgs in the present study may be due to the protein nature of extracellular secretion of B.mellitensis which is considered a good stimulator of cell mediated immune responses, these observation was supported the idea that recorded by (10) .who explained that CFAgs of S.aureus stimulated cellular and hummral immunity . The differences between mean values of the skin thickness against CFSAgs and SSSAgs in the present study may be due to antigen specifity and protein concentration in both antigens which may be high in the SCFAgs ,these observations were in consistence with (11), who explained that the protein antigens were a better stimulator of APCs and $\mathrm{T}$ cells that produced INF-y and TNFalpha which play important role in expression of DTH. and humoral immune responses, these result may be indicated that these type of Ags elicited both subsets of Th1 which responsible for CMI and and Th2 which responsible for proliferation and differentiation of B-lymphocytes to plasma produsing antibodies ,these suggestion was supported by idea of (12)who found that immunized mice with soluble Brucella antigens stimulated spleen cells of these animals to generate $\mathrm{Th} 2$ response which play mainly role in stimulated humeral immunity Our observation revealed that animals immunized either with CFBMAgs fed diet supplement with chitosan expressed high level of DTH and antibody titers ,these finding may indicated that chitosan agument both arms of immune response,these idea was agreement with (6)explained that immunized mice with viscous chitosan solution stimulated cellular and humeral immunity.also the present study found that immunized animals with CFBMAgs + chitosan expressed high values of DTH and Abs titers as compare with other groups ,these result may be indicated that chitosan strength the immune response induced by CFBMAgs these idead was agreed with observation of (13), who said that the Chitosan has been used as an immunostimulant for protection against bacterial disease in fish, and as a diet supplement .

\section{Clinical signs and bacterial isolation:}

There is clear clinical symptoms noticed on non-immunized infected animals particulary during the first month postinfection, and these clinical symptoms characterized by loss apappitate, losse movament, and 4 animals died during first 
15 days post-infetion while no clear clinical symptoms noticed on immunized infected animals during the course of the study .Bacterial isolation were variable according to protocol of immunization and the period of sacrific but the levels bacterial growth in non-immunized infected animals were high during 15-35 days post infection as compare with immunized animals. Our finding was agreement with (14) who said that the responses of mice for virulent brucellae are more severe as compare with immunostimulated mice .

Pathological examination: Gross examination:

Infected The Gross examination of the internal organs of control challenged died mice during the first 15 days . post challenge demonstrated severe congestion of those organs, while no clear gross lesions were reported in examined organs of immunized challenged animals.

Histopathological examination:

Non-immunized infected animals at day 30 post-infection

\section{Lung}

The lung showed hyperplasia of the epithelial lining cells of bronchiol more extensive than those noticed at (30) in addition to congestion blood vessels with neutrophils in their lumen (Fig:23)

liver

Histopathological examination revealed multigranulomatous lesions in the liver parenchyma consisting from aggregation of macrophages(Fig:15)

liver

Histopathological examination revealed to dilated of the sinusoids with mononuclear cells in their lumen (Fig:17)

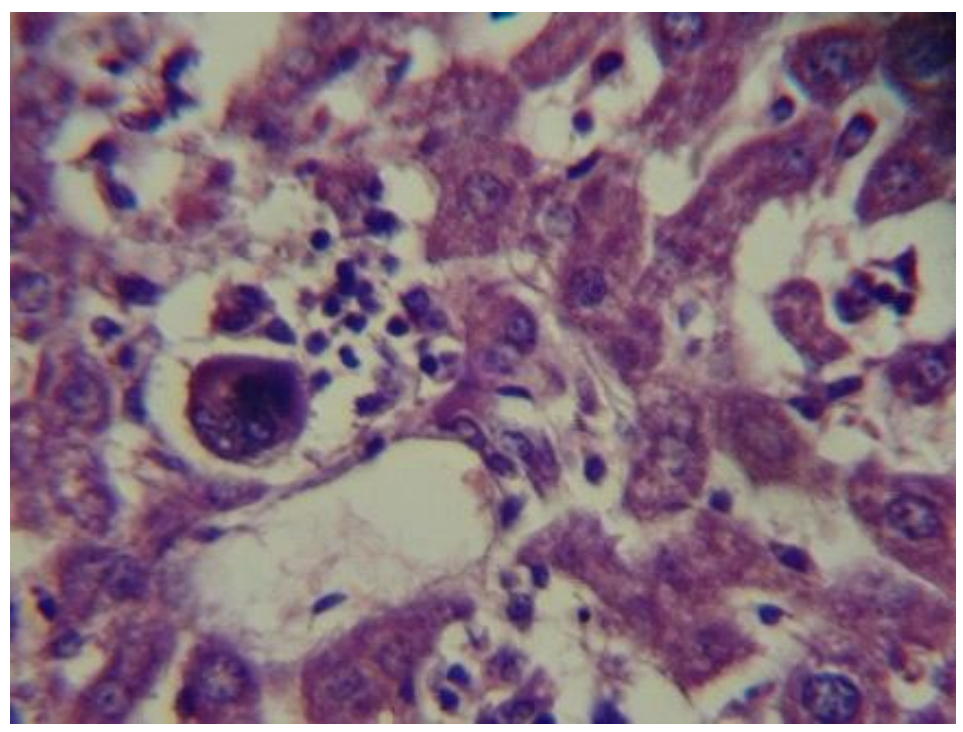

Fig: 17.Histopathological section in the liver of animal at 3o days post-infection shows focal aggregation of mononuclear cells in the liver parenchyma with present of megakerocyte $(\mathrm{H} \& \mathrm{E}$ stain $40 \mathrm{X})$ 


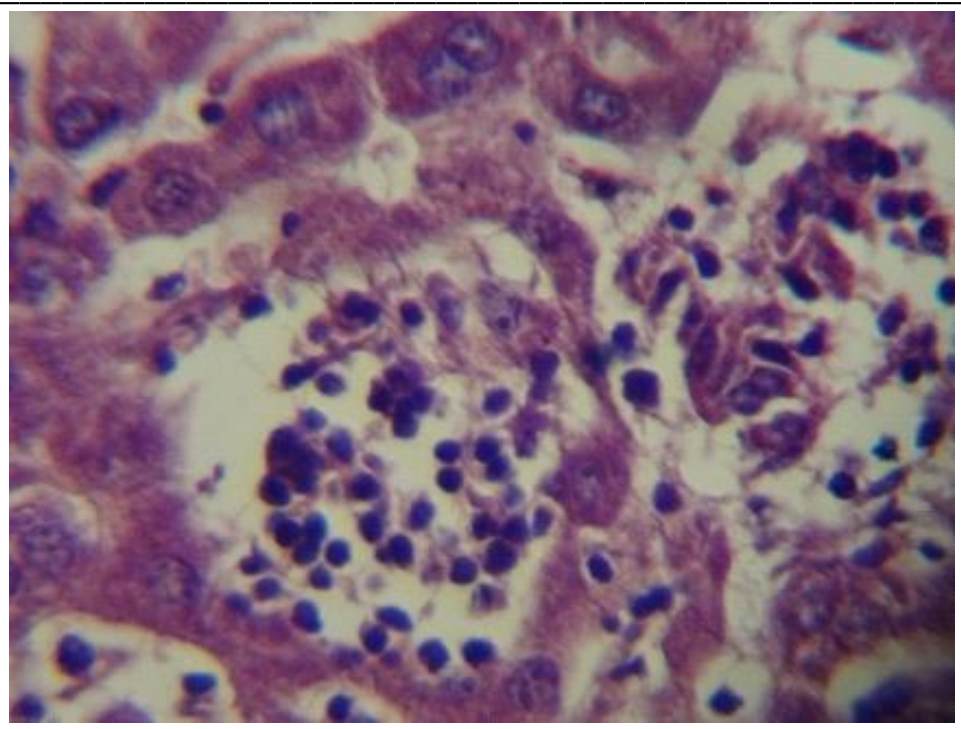

Fig:15. Histopathological section in the liver of animal at 30 days post-infection shows multiple granulomatous lesions in the liver parenchyma ( $\mathrm{H} \& \mathrm{E}$ stain $4 \mathrm{Ox}$ )

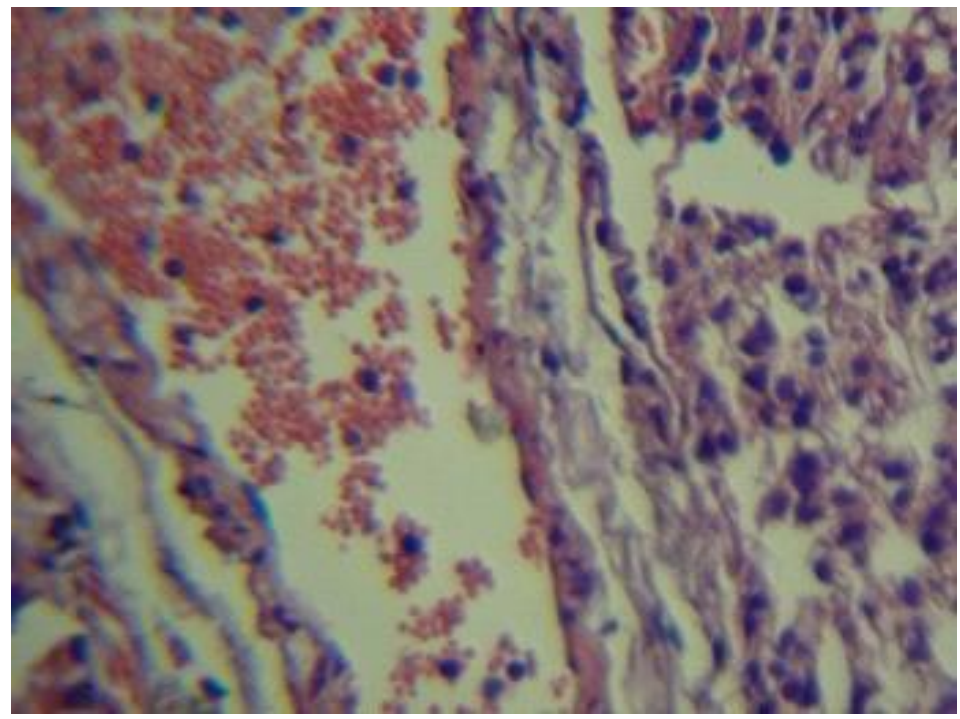

Fig:23. Histopathological section in the lung of animal at 3o days post-infection shows congested blood vessels with neutrophils in their lumen as well as in wall and space of alveoli $(\mathrm{H} \& \mathrm{E}$ stain $40 \mathrm{X})$

\section{Immunized animals with CFBAgs at 30 days \\ Liver}

Multipe granulomatous lesions consisting from activated macrophage and lymphocytes were seen in the liver parenchyma and around the central veins(Fig:35.36).

\section{Kidney}

also mononuclear cells particularly lymphocytic cells aggregation in the interstitial tissue of the kidney more intensity than that recorded in day 15 postinfection(Fig:38). 


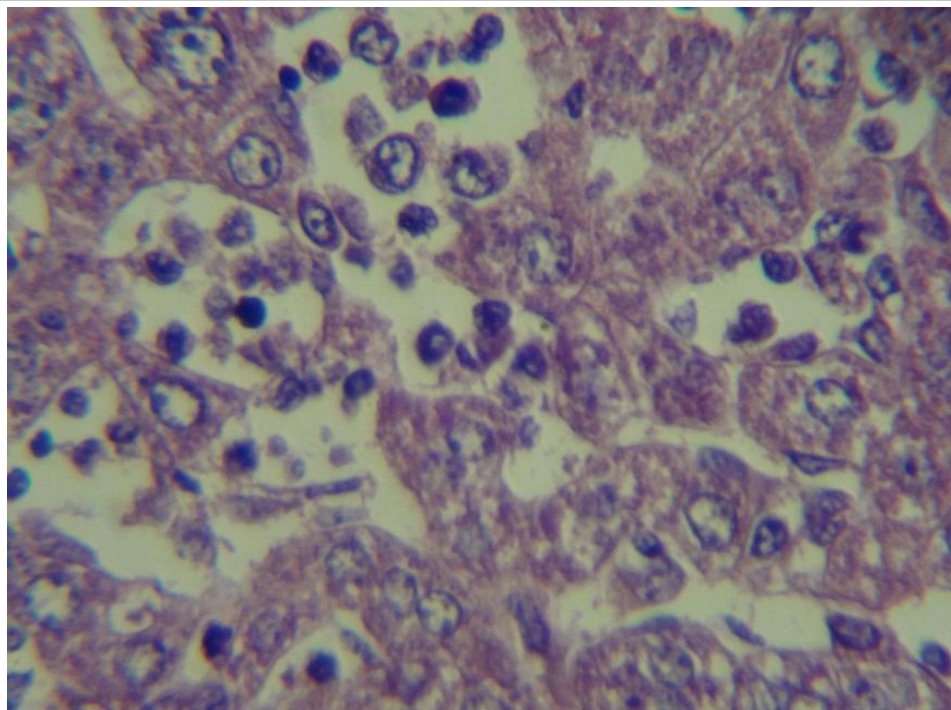

Fig:35Histological section liverof immunized animal withCFBMAgs at 30days post-infection shows multiple granulomatous lesions with kupffer cells (H\&E stain 40X)

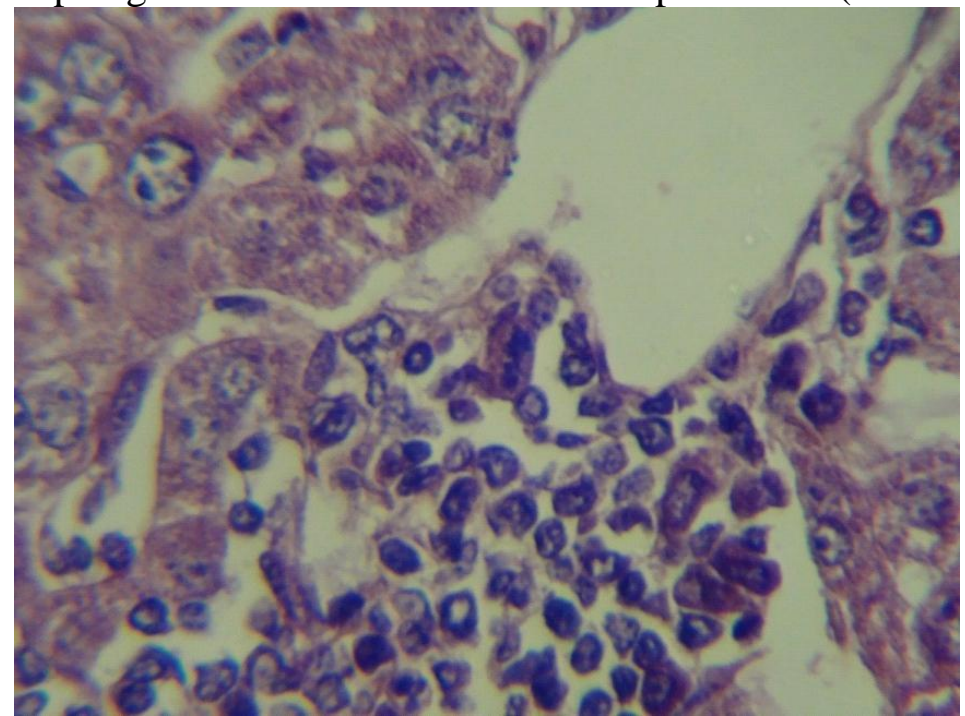

Fig:36.Histological section in the liver of immunized animal withCFBMAgs at 30days postinfection shows granulomatous lesions in one side of central veins with proliferation of cupffer cells $(H \& E$ stain $40 X)$ 


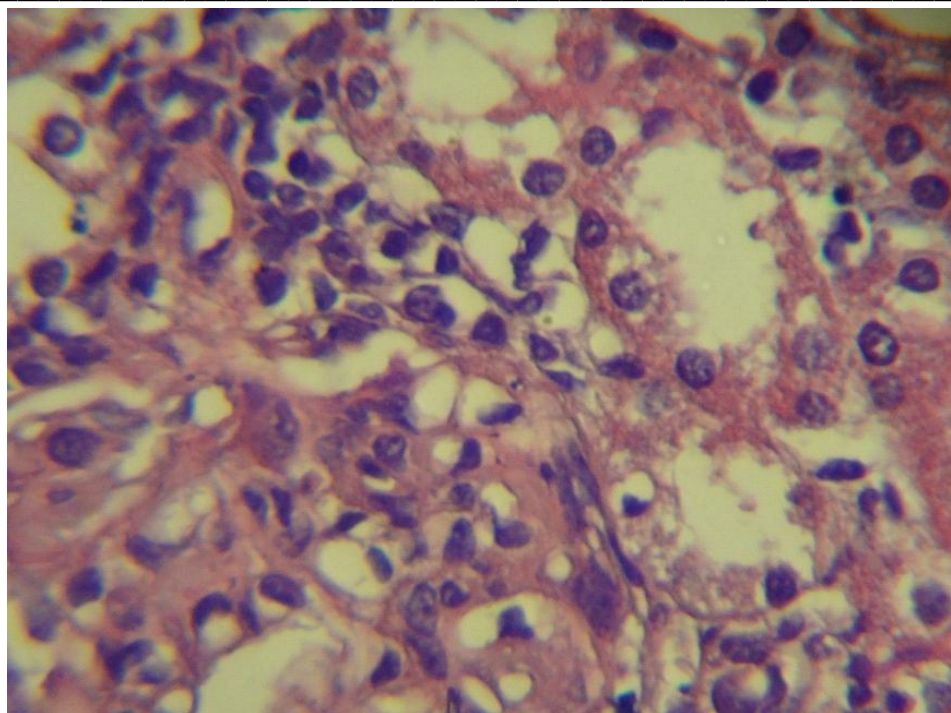

Fig:38.Histological section in the kidney of immunized animal withCFBMAgs at 30days postinfection shows mononucler cells aggregation in the interstitial tisues(H\&E stain 40X)

Immunized animals with CFBAs+fed on diet supplement with chitosan At day 30 post-infection liver

The no clear lesions in the liver except proliferation of kupffer cells(Fig:80), Spleen the spleen showed marked hyperplasia of white pulp and proliferation of mononuclear cells around the sinus of red $\operatorname{pulp}$ (Fig:81).

\section{Lung}

hyperplasia of the epithelial lining cells of bronchiol with hyperplasia of lymphoid tissue in the wall of the airways(82),

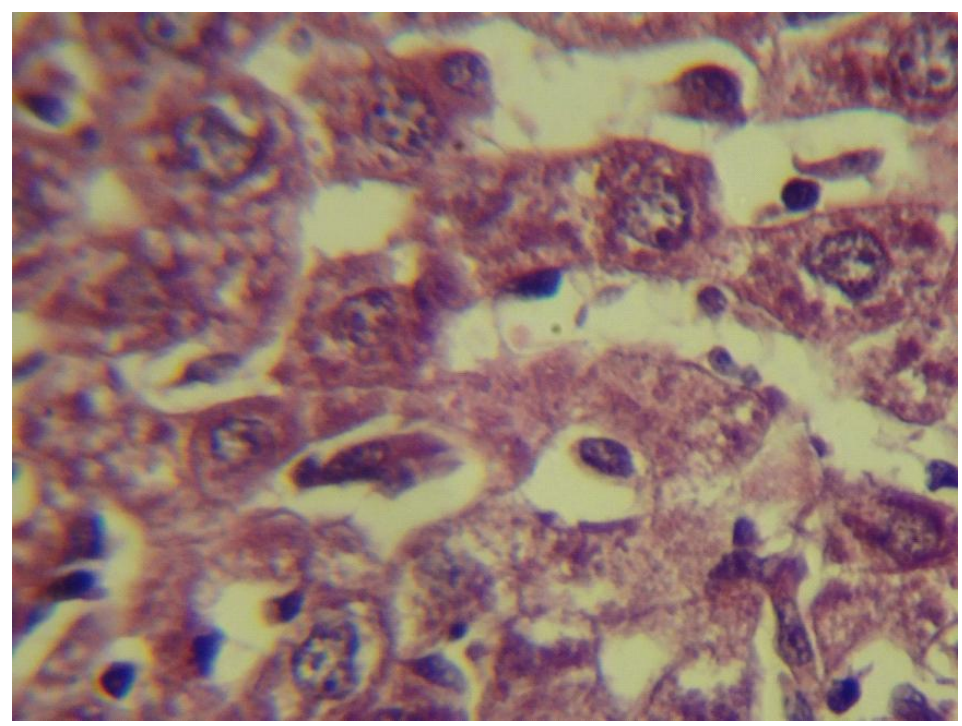

Fig:80. Histopathological section in the liver of immunized animal with CFBAgs+chitosanat day 30 post-infection shows proliferation of kupffer cells (H\&Estain40X) 


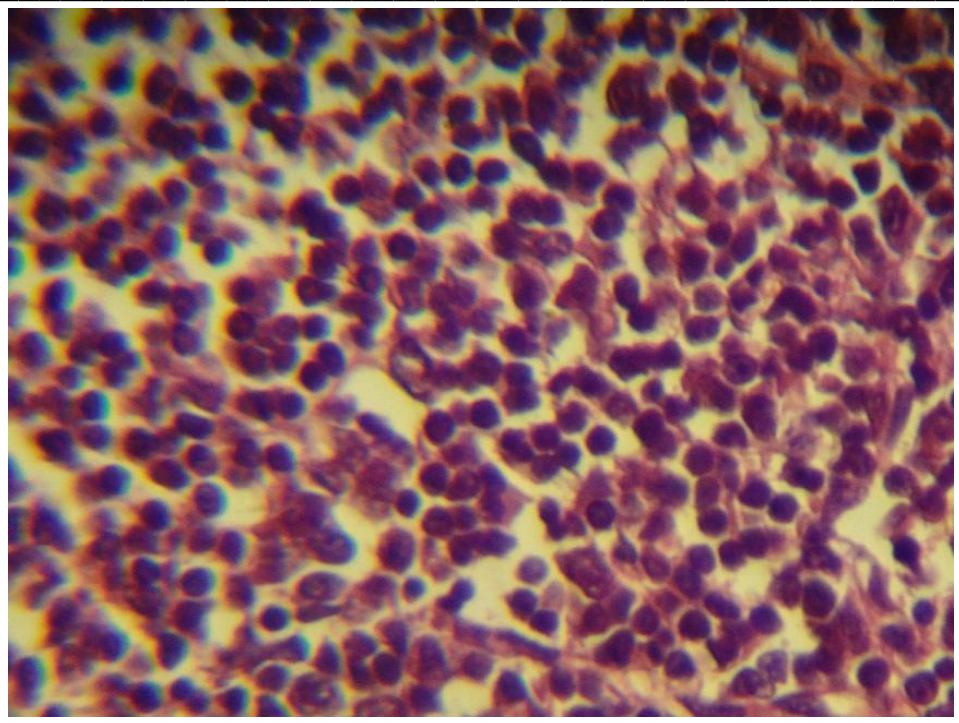

Fig:81. Histopathological section in the spleen of immunized animal with CFBAgs+chitosan at day 30 post infectionshows marked proliferation of lymphocytes in the periarteriolar sheath (H\&E stain 40X).

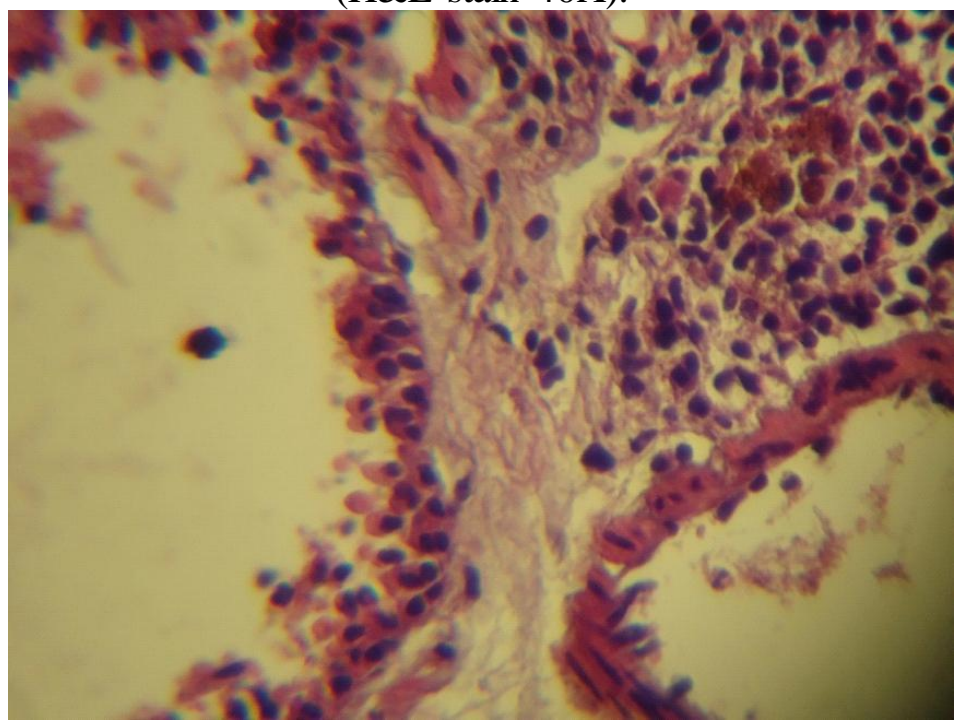

Fig: 82.Histopathological section in the lung of immunized animal with CFBAgs+chitosan at day 30 post-infection shows marked proliferation of the epithelial lining cells of the bronchiol mononuclear cells aggregation in the wall of the blood vessels (H\&Estain $40 \mathrm{X})$

In the r present r study
Histopathological examination showed
severe lesions in the examined organs of
non-immunized infected animals
particularly the liver and spleen,these
result may be indicated that the Brucella
strain using in the present study overcome
the normal defense mechanism of these
organs,these result in consistent with(12),
acute inflammatory response against

bacterial infection and starting of cell mediated immune response that induced granulomatous reaction, these investigation was in consistent with(15) who explained that the acute phase of brucellosis start from day three to $2^{\text {nd }}$ and $3^{\text {rd }}$ week and these stage characterized by rapid increase in number of bacteria in the target organs particularly spleen and liver.while immunized animal We recorded moderate 
pathological lesion in the examined organs of immunized animals with CFBMAs at day 30 post-challenge with B.melitensis ,these result may be indicated that these Ags provided a partial protection,these idea was supported by( Cassataro et al.,2005) who recoeded that immunized mice with Omp31 stimulated a CD4+ Th1 response which provided partial protection against B.melitensis infection also we recorded We recorded that the intensity of pathological lesions in immunized animals with $\mathrm{C}$ f B Ags and feed diet supplementing chitosan lower as comparing with those in non-immunized infected anmals, immunized animals fed diet not supplement with chitosan,these results also supported out results of immunity and bacterial isolation and supported idea that chitosan activated and strength immune responses .these finding was agreement with (Asiad,2012 )who suggested that chitosan strength both cellular and humoral immune responses .

\section{Reference}

1- Gul, S. T. and A. Khan, 2007. Epidemiology andepizootology of brucellosis: A review. Pakistan Vet.J., 27(3): 145-151.

2- Godfroid J, Cloeckaert A, Liautard JP, Kohler S, Fretin D, Walravens K, Garin-Bastuji B, Letesson JJ: From the discovery of the Malta fever's agent to the discovery of a marine mammal reservoir, brucellosis has continuously been a re-emerging zoonosis. Vet Res 2005, 36(3):313326

3- Yuan, Z. (2007).study on the synthesis and catalyst oxidation properties of chitosan bound nickel (II) complexes .Agaric . foodChem . (HuagongShikanZazhishe) 21; 2224.

4- David, A.Z.; Connie, J.R.; Kenneth W.H.; Jeffrey, S. and John, W.G. (2006). Chitosan solution enhances both humoral and cell-mediated immune responses to subcutaneous vaccination. 37: 21-27

5-Schurig GG, Sriranganathan N, Corbel MJ. Brucellosis vaccines: past, present and future. Vet Microbiol. 2002; 90: 479-96.

6- Salwa,A.S. (2012). Effect of hypercholesterolemia , chitosan and whole sonicated E.coli Ags on immune response and pathological changes in mice infected with E.coli (O:127) isolated from children suffering from diarrhea. Thesis faculty of veterinary medicine ,Baghdad university

7- Miles, A.A.; Misra, S.S. and Irwin, J.O. (1938). The estimation of the bactericidal power of blood. J. Hyg. Camp., 38: 739-749.

8-. Hudson, L. and Hay, F.C. (1980). "Practical Immunology". $3^{\text {rd }}$ Ed. Blackwell Scientific Publication, Oxford. London.

9-Herbert, W.J. (1978). Passive heamagglutination with special reference to the tanned cell technique. Ch. 20, In : Weir, D. M. "Handbook of Experimental Immunology". (3 ${ }^{\text {rd }}$ Ed.) Vol. II, Cellular Immunology. Blackwell Scientific Publication, 20: 1-20.

10-- Hassan Hadi Khorsheed AL-Bayaty . Study of the Pathological Changes Inducing by Staphylococcus aureus in Immunodeficiency Mice(balb/c) Using Mitomycin C Treated with Some Immunostimulators.,2012;57-60

11-Bullock, G.;Blazer, V.; Tsukuda, S. and Summerfelt, S. (2000). Toxicity of acidified chitosan for cultured rainbow trout (Oncorhynchus mykiss). Aquacul. 185 (3-4): 272280.

12- Zhan YF, Stanley ER, Cheers C: Prophylaxis or treatment of 


experimental brucellosis with
interleukin-1. Infect Immun 1991,

13- Belkaid, Y. and Rouse, B. T. (2005). "Natural regulatory $\mathrm{T}$ cells in infectious disease." Nat Immunol 6(4): 353-60.

14-16- Ko J, Gendron-Fitzpatrick A, Ficht TA, Splitter GA: Virulence criteria for Brucella abortus strains as determined by interferon regulatory factor 1-deficient mice. Infect Immun 2002, 70:70047012.1

15- Fernández-Lago L, Orduña A, Vizcaíno N: $\quad$ Reduced interleukin-18 secretion in Brucella abortus 2308- infected murine peritoneal macrophages and in spleen cells obtained from B abortus 2308infected mice. J Med Microbiol 2005, 54:527-531.

16-Cassataro, J., C. A. Velikovsky, S. de la Barrera, S. M. Estein, L. Bruno, R. Bowden, K. A. Pasquevich, C. A. Fossati, and G. H. Giambartolomei. 2005. A DNA vaccine coding for the Brucella outer membrane protein 31 confers protection against $B$. melitensis and $B$. ovis infection by eliciting a specific cytotoxic response. Infect. Immun. 73:6537-6546

\title{
التغيرات المرضية المحدثة بواسطة بكتريا البروسيلا في الفئران الممنعة

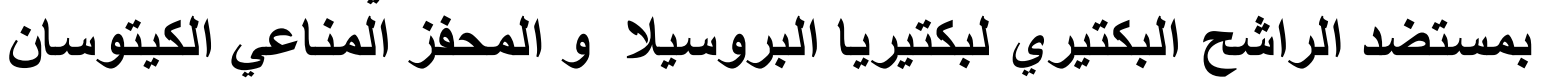

\author{
اسعد موحان محمد الناشي محمد جويد علوان الجبوري \\ كلية الطب البيطري /جامعة بغداد
}

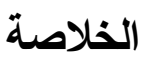

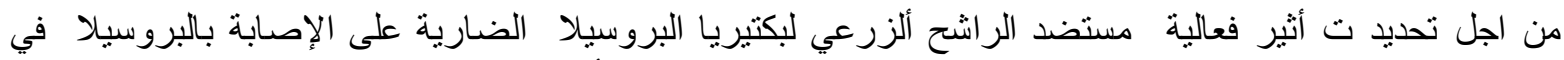

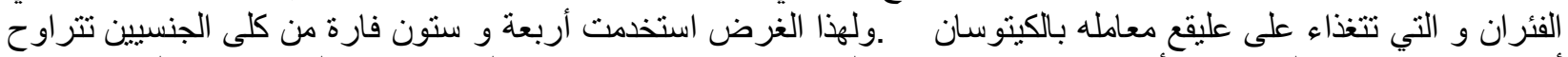

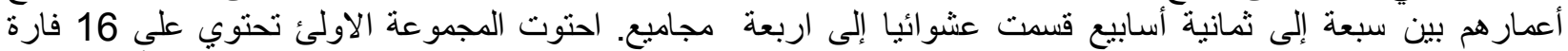

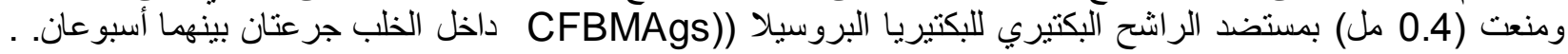

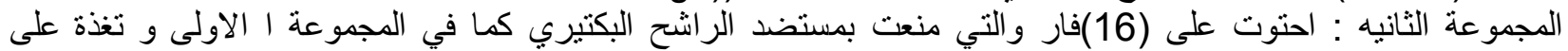

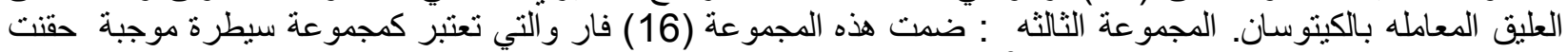

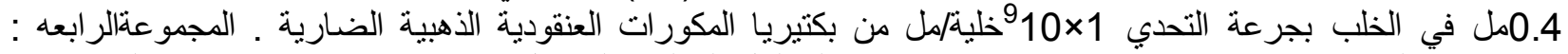

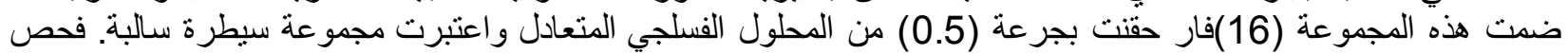

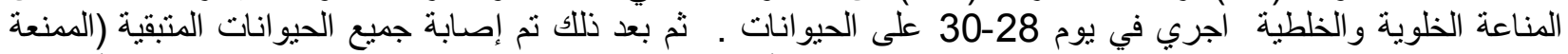

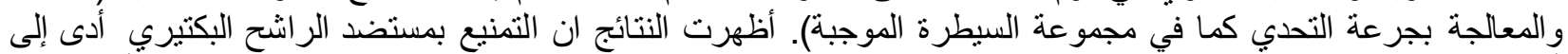

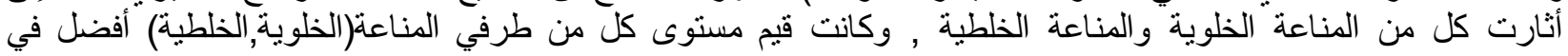

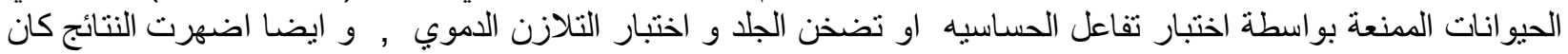

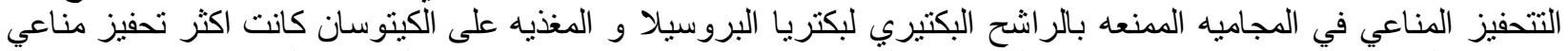

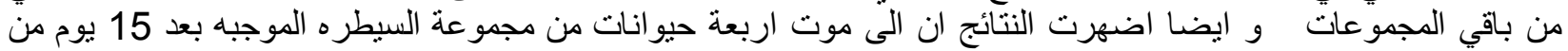

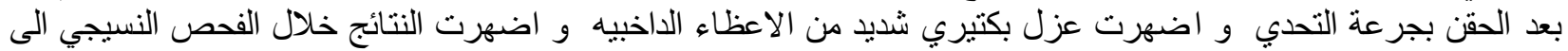

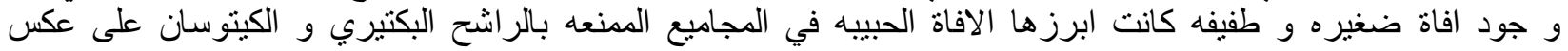

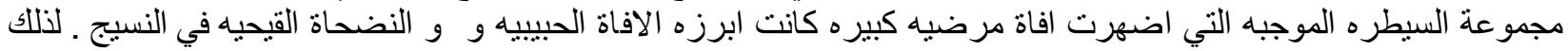

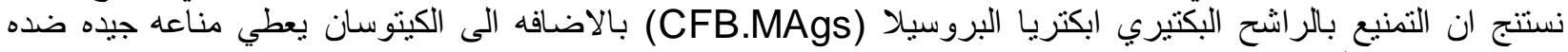
Brucella mellitensis الاصنابه ببكتري البرو البنيل 